Research Article

\title{
Assessment of socio-demographic determinants of psychiatric patients attending psychiatry outpatient department of a tertiary care hospital of Central India
}

\author{
Paharam Adhikari $^{1 *}$, Anjana Niranjan ${ }^{1}$, Sunil Kumar Ahuja ${ }^{2}$, Neeraj Gour ${ }^{3}$, Sanjeev Kumar $^{1}$, \\ Manish Kumar ${ }^{1}$
}

${ }^{1}$ Department of Community Medicine, S. S. Medical College, Rewa, MP, India

${ }^{2}$ Department of Psychiatric, S. S. Medical College, Rewa, MP, India

${ }^{3}$ Department of Community Medicine, Government SHK Medical College, Mewat, Haryana, India

Received: 11 January 2016

Revised: 11 February 2016

Accepted: 19 February 2016

\section{*Correspondence:}

Dr. Paharam Adhikari,

E-mail: dradhikari2002@gmail.com

Copyright: ( ) the author(s), publisher and licensee Medip Academy. This is an open-access article distributed under the terms of the Creative Commons Attribution Non-Commercial License, which permits unrestricted non-commercial use, distribution, and reproduction in any medium, provided the original work is properly cited.

\begin{abstract}
Background: Mental disorders are among the most burdensome in the world, and their burden will increase over the next decades. The mental and behavioral disorders account for about $12 \%$ of the global burden of disease. By 2020 , it is likely to increase to $15 \%$. Depression, OCD, schizophrenia, anxiety, phobia and bipolar disorders constitute the top 10 conditions contributing to the global burden of disease among mainly the age group of 15-44 years. In India, little is known about the extent, severity and unmet need of treatment of mental disorders. The objective of the study was to assess the socio-demographic determinants of psychiatric patients.

Methods: This was an observational cross sectional study which was undertaken in a psychiatric outpatient department (OPD) of a tertiary care hospital (S.G.M.H) affiliated to S. S. Medical College Rewa, MP, India. The total sample size was 108; it was collected randomly by face to face interviews with the help of pre-designed questionnaire based proforma. All new cases were selected in the study. Duration of study was three months i.e. from $1^{\text {st }}$ November 2014 to 30 January 2015. Data were analysed by using EPI info 2000.

Results: Out of total 108 interviewed patients, $59.25 \%$ were males $40.74 \%$ were female; most of them (45.37\%) were belong to age group of 21-40 years. Mental disorders (78.70\%) were more common in un-married or separated patients. In case of educational status most of them $(87.96 \%)$, belong to low education status. Depression was most common mental illness $43(39.81 \%)$ among of all types of disorders.

Conclusions: As per the findings of the present study it can be concluded that there must be a kin observation for prevention and control of mental disorders over particularly low educational status group and unmarried/separated group of people hence mental disorders are more common among of those group. Infact we need more studies for validate our findings.
\end{abstract}

Keywords: Psychiatric illness, OPD, Patients

\section{INTRODUCTION}

Psychiatric illnesses are commonly associated with a higher disability but rarely come in attention to a physician than any other physical illnesses. The World Health Organization noted that one in every four people are affected by a mental disorder at some stage of life. ${ }^{1}$
Six neuropsychiatry diseases like unipolar depressive disorders, alcohol use disorders, schizophrenia, bipolar affective disorder, alzheimer's, and other dementias, as also migraine, have figured in the top 20 causes of disability in the world. ${ }^{2}$ The WHO global burden of disease study estimates that mental disorders are among the most burdensome in the world, and their burden will 
increase over the next decades. The mental and behavioural disorders account for about $12 \%$ of the global burden of disease. By 2020, it is likely to increase to $15 \%$. It is estimated that at any point in time, in India, $2-5 \%$ of the population is suffering from serious mental illnesses, while another $10 \%$ of the population is suffering with minor mental illnesses. ${ }^{3}$ In India, little is known about the extent, severity and unmet need of treatment of mental disorders. Few studies on the epidemiology of mental disorders have focused on prevalence at their isolated sites. The meta-analysis of available Indian studies carried out by Reddy and Chandrasekhar revealed the overall prevalence of mental disorders as $5.8 \%$ among the population. ${ }^{4} \mathrm{~A}$ review analysis of 15 epidemiological studies by Ganguli on the prevalence of mental disorders in India estimated the national prevalence of all mental disorders as 70.5 per 1000 in the rural and 73 per 1000 in the urban population..$^{5}$ In India, there are a very small number of qualified psychiatrists, mostly concentrated in the metropolitan and the urban areas, to deal with this huge problem, further compounding the issue. ${ }^{6}$ Furthermore, it is a general observation in India that a majority of patients with mental disorder never seek professional help; and most of them utilize the help of unqualified medical practitioners, faith healers, and so on. The nonavailability of mental health services, stigma, and superstitions associated with mental disorders, coupled with the unwillingness or inability of families to care for their mentally ill relatives, appear to be the main contributory factors. ${ }^{7}$ This implies that the stigma of mental illness can be reduced by education and experience, and an examination of attitudes towards mental illness should be included in medical training. ${ }^{8}$ Depression, OCD, schizophrenia, anxiety, phobia and bipolar disorders constitute the top 10 conditions contributing to the global burden of disease among the age group of 15-44 years. Mental and behavioural disorders are present, in about $10 \%$ of the adult population, at any given point of time. ${ }^{9}$ The prevalence of schizophrenia in India is about $1 \%$, this may be due to diagnostic drawbacks rather than decreased number of cases. ${ }^{10}$ The etiological factors involved in the pathogenesis of the disease include genetic predisposition (60\% concordance rates in monozygotic twins), family environment (presence of stressors \& disease among other family members), viral infection (inconclusive proof), cerebral infections and neurotransmitter disturbances at any given point of time. ${ }^{11-13}$ However, these estimates and projections are based largely on literature review rather than cross-national epidemiological surveys. In India, little is known about the extent, severity and unmet need of treatment of mental disorders. So this study is done to understand the type of psychiatric problem in the patients attending this facility, and to explore their socio-demographic variables which may responsible for the same with the objective of to find out the various types of psychiatric illness among patient attending psychiatric OPD along with an assessment of socio-demographic determinants of psychiatric patients.

\section{METHODS}

This was a hospital-based prospective cross sectional study, conducted at the psychiatric outpatient department of a tertiary care hospital (S.G.M.H) affiliated to S. S. Medical College Rewa of Central India. The Psychiatry department of the medical college was located at this hospital. The study subjects were the newly enrolled patients at the OPD hours of 10:00 AM to 12:00 Noon with psychiatric illnesses diagnosed by the psychiatrist during his consulting days within the study period of three months from $1^{\text {st }}$ Nov 2014 to $30^{\text {th }}$ Jan 2015 . Total new patient who visited at above mentioned OPD time of $2 \mathrm{hrs}$ and diagnosed as psychiatric illness by the consultant were 145 , out of which 30 patients were not willing to participate in the study and 7 were unable to give required information hence excluded from the study. So that in the present study the interviewed sample size was 108 , it was collected by investigator (face to face interviews) at OPD site during mentioned OPD hours at psychiatric department with the help of pre-designed questionnaire based proforma. Proformas meant for collection of quantitative and qualitative information about the study subjects. The clinical information and the interview schedule were used for data collection by interviewing either the patient or the informant or both, as appropriate. In case, it was noticed that patient was not able to give the correct history, the informants were interviewed and efforts were made to verify that information. The patients with psychotic disorder were less likely to give correct information, and therefore, information from the caregivers was also used. As the cases were worked up in detail; if at any stage of the study it was found that it was not the first contact with any psychiatric health facility, those subjects were not included in the final data analysis. The diagnosis was finally given, after complete history and clinical examination by psychiatric consultant. The study protocol was approved by the experts of community medicine department of the Shyam Shah Medical College Rewa, MP, India.

Data was collected only after their informed consent was gained. Those subjects who were old cases and reported for follow up at OPD were not included, because such cases might have added to the recall bias. Patients who were not willing to participate and not able to interrogate were also excluded from the study. Hence it was limited time bound study on a small scale so that no ethical consideration was taken from the ethical committee of medical college although verbal permission was taken from psychiatric consultant.

The data was analysed using the Epicalinfo 2000 and simple calculator. $\mathrm{P}$ value of $<0.05$ was considered statistically significant and $>0.05$ was considered statistically not significant. 


\section{RESULTS}

Table 1: Age and sex wise distributions of patients.

\begin{tabular}{|lllll|}
\hline \multicolumn{2}{|l|}{$\begin{array}{l}\text { Age } \\
\text { distribution }\end{array}$} & Gender distribution & \\
\hline S.N & $\begin{array}{l}\text { Age- } \\
\text { group } \\
\text { (Yrs.) }\end{array}$ & Female & Male & No. of cases \\
\hline 1 & $0-20$ & 10 & 7 & $17(15.74 \%)$ \\
\hline 2 & $21-40$ & 17 & 32 & $49(45.37 \%)$ \\
\hline 3 & $41-60$ & 11 & 16 & $27(25 \%)$ \\
\hline 4 & $61-80$ & 3 & 9 & $12(11.11 \%)$ \\
\hline 5 & $>80$ & 3 & 00 & $3(2.77 \%)$ \\
\hline & Total & 44 & 64 & $108(100 \%)$ \\
\hline
\end{tabular}

Chi square $=8.64 ; \mathrm{p}=0.07$

In the present study the interviewed sample size was 108 . Table 1 shows that the majority of these patients were in the age group of 21-40 year (49) $45.37 \%$, followed by 41 -
60 years (27) $25 \%$, then $0-20$ year (17) $15.74 \%, 61-80$ years (12) $11.11 \%$, least one was found are patient age $>80$ years only 3 case $2.77 \%$. Out of these (44) $40.74 \%$ are female and $64(59.25 \%)$ are male. The overall distribution of age wise in relation to sex-wise found statistically not significant $(\mathrm{p}=0.07)$.

Table 2: Distribution of various psychiatric illness.

\begin{tabular}{|llll|}
\hline S.N. & $\begin{array}{l}\text { Psychiatric } \\
\text { illness }\end{array}$ & $\begin{array}{l}\text { No. of } \\
\text { cases }\end{array}$ & $\begin{array}{l}\text { Percentage of } \\
\text { cases }(\%)\end{array}$ \\
\hline 1 & Depression & 45 & 41.66 \\
\hline 2 & Mania & 25 & 23.14 \\
\hline 3 & BPD & 22 & 20.37 \\
\hline 4 & Anxiety & 22 & 20.37 \\
\hline 5 & Schizophrenia & 15 & 13.88 \\
\hline 6 & OCD & 13 & 12.03 \\
\hline 7 & Phobia & 9 & 8.33 \\
\hline Total & & 108 & 100 \\
\hline
\end{tabular}

Table 3: Socio-demographic profile of psychiatric patients.

\begin{tabular}{|c|c|c|c|}
\hline S.N. & Social demographic variables & No. of mothers & Percentage $(\%)$ \\
\hline 1. & $\begin{array}{l}\text { Religion } \\
\text { Hindu } \\
\text { Muslim } \\
\text { Others }\end{array}$ & $\begin{array}{l}85 \\
21 \\
2\end{array}$ & $\begin{array}{l}78.70 \\
19.44 \\
1.85\end{array}$ \\
\hline 2. & $\begin{array}{l}\text { Caste } \\
\text { General } \\
\text { OBC } \\
\text { ST } \\
\text { SC } \\
\end{array}$ & $\begin{array}{l}46 \\
32 \\
21 \\
9\end{array}$ & $\begin{array}{l}42.59 \\
29.62 \\
19.44 \\
8.33\end{array}$ \\
\hline 3. & $\begin{array}{l}\text { Education } \\
\text { Illiterate } \\
\text { Up to primary } \\
\text { Up to middle } \\
\text { Up to High School } \\
\text { Up to Higher Secondary } \\
\text { Graduate } \\
\text { Post Grad. }\end{array}$ & $\begin{array}{l}25 \\
18 \\
21 \\
17 \\
14 \\
11 \\
2\end{array}$ & $\begin{array}{l}23.14 \\
16.66 \\
19.44 \\
15.74 \\
12.96 \\
10.18 \\
1.85\end{array}$ \\
\hline 4. & $\begin{array}{l}\text { Socio-Economic status } \\
\text { Class I } \\
\text { Class II } \\
\text { Class III } \\
\text { Class IV } \\
\text { Class V }\end{array}$ & $\begin{array}{l}3 \\
9 \\
22 \\
34 \\
40\end{array}$ & $\begin{array}{l}2.77 \\
8.33 \\
20.37 \\
31.48 \\
37.03\end{array}$ \\
\hline 5. & $\begin{array}{l}\text { Living status } \\
\text { Married } \\
\text { Un-married } \\
\text { separated } \\
\text { Widowed }\end{array}$ & $\begin{array}{l}30 \\
43 \\
49 \\
6\end{array}$ & $\begin{array}{l}27.77 \\
39.81 \\
45.37 \\
5.55\end{array}$ \\
\hline
\end{tabular}


Table 4A: Types of more prevalent psychiatric illness in relation with different socio demographic variables.

\begin{tabular}{|c|c|c|c|c|c|c|c|}
\hline \multirow{2}{*}{ Type of illness } & \multicolumn{7}{|c|}{ Number of patients in different socio demographic groups } \\
\hline & Age & Sex & Education Status & SES & Religion & Caste & Marital status \\
\hline Depression & $\begin{array}{l}0-20=2 \\
21-40=23 \\
41-60=12 \\
61-80=6 \\
>80=00\end{array}$ & $\begin{array}{l}\mathrm{M}=13 \\
\mathrm{~F}=32\end{array}$ & $\begin{array}{l}\text { Ill-literate }=11 \\
\text { Primary }=6 \\
\text { Middle }=7 \\
\text { High school=7 } \\
\text { High Secondary=8 } \\
\text { Graduate=5 } \\
\text { Post Graduate=1 }\end{array}$ & $\begin{array}{l}1=1 \\
2=3 \\
3=9 \\
4=15 \\
5=17\end{array}$ & $\begin{array}{l}\text { Hindu=29 } \\
\text { Muslim }=16 \\
\text { Other }=00\end{array}$ & $\begin{array}{l}\mathrm{GEN}=22 \\
\mathrm{OBC}=12 \\
\mathrm{ST}=8 \\
\mathrm{SC}=3\end{array}$ & $\begin{array}{l}\text { Married=7 } \\
\text { Un-married=23 } \\
\text { Separated }=14 \\
\text { Widowed=1 }\end{array}$ \\
\hline Mania & $\begin{array}{l}0-20=5 \\
21-40=12 \\
41-60=6 \\
61-80=2 \\
>80=00\end{array}$ & $\begin{array}{l}\mathrm{M}=17 \\
\mathrm{~F}=8\end{array}$ & $\begin{array}{l}\text { Ill-literate }=4 \\
\text { Primary }=6 \\
\text { Middle }=6 \\
\text { High school }=5 \\
\text { High Secondary }=2 \\
\text { Graduate }=2 \\
\text { Post Graduate }=00\end{array}$ & $\begin{array}{l}1=6 \\
2=7 \\
3=5 \\
4=3 \\
5=4\end{array}$ & $\begin{array}{l}\text { Hindu=18 } \\
\text { Muslim }=6 \\
\text { Other }=1\end{array}$ & $\begin{array}{l}\mathrm{GEN}=9 \\
\mathrm{OBC}=7 \\
\mathrm{ST}=4 \\
\mathrm{SC}=5\end{array}$ & $\begin{array}{l}\text { Married=5 } \\
\text { Un-married=11 } \\
\text { Separated=8 } \\
\text { Widowed=1 }\end{array}$ \\
\hline BPD & $\begin{array}{l}0-20=1 \\
21-40=6 \\
41-60=8 \\
61-80=7 \\
>80=00\end{array}$ & $\begin{array}{l}\mathrm{M}=13 \\
\mathrm{~F}=9\end{array}$ & $\begin{array}{l}\text { Ill-literate }=3 \\
\text { Primary }=5 \\
\text { Middle=3 } \\
\text { High school=5 } \\
\text { High Secondary=4 } \\
\text { Graduate }=2 \\
\text { Post Graduate }=00\end{array}$ & $\begin{array}{l}1=1 \\
2=1 \\
3=4 \\
4=6 \\
5=8\end{array}$ & $\begin{array}{l}\text { Hindu }=16 \\
\text { Muslim }=6 \\
\text { Other }=00\end{array}$ & $\begin{array}{l}\mathrm{GEN}=8 \\
\mathrm{OBC}=6 \\
\mathrm{ST}=5 \\
\mathrm{SC}=3\end{array}$ & $\begin{array}{l}\text { Married=4 } \\
\text { Un-married=7 } \\
\text { Separated=8 } \\
\text { Widowed=3 }\end{array}$ \\
\hline Anxiety & $\begin{array}{l}0-20=6 \\
21-40=8 \\
41-60=6 \\
61-80=2 \\
>80=00\end{array}$ & $\begin{array}{l}\mathrm{M}=4 \\
\mathrm{~F}=18\end{array}$ & $\begin{array}{l}\text { Ill-literate }=2 \\
\text { Primary }=4 \\
\text { Middle }=4 \\
\text { High school=5 } \\
\text { High Secondary=5 } \\
\text { Graduate }=1 \\
\text { Post Graduate=1 }\end{array}$ & $\begin{array}{l}1=00 \\
2=2 \\
3=5 \\
4=8 \\
5=7\end{array}$ & $\begin{array}{l}\text { Hindu=14 } \\
\text { Muslim=8 } \\
\text { Other= }\end{array}$ & $\begin{array}{l}\mathrm{GEN}=10 \\
\mathrm{OBC}=7 \\
\mathrm{ST}=3 \\
\mathrm{SC}=2\end{array}$ & $\begin{array}{l}\text { Married=7 } \\
\text { Un-married=8 } \\
\text { Separated=5 } \\
\text { Widowed }=2\end{array}$ \\
\hline
\end{tabular}

Table 4B: Types of less prevalent psychiatric illness in relation with different socio demographic variables.

\begin{tabular}{|c|c|c|c|c|c|c|c|}
\hline \multirow[t]{2}{*}{ Type of illness } & \multicolumn{7}{|c|}{ Number of patients in different socio demographic groups } \\
\hline & Age & Sex & Education level & Ses & Religion & caste & Marital status \\
\hline Schizophrenia & $\begin{array}{l}0-20=00 \\
21-40=1 \\
41-60=4 \\
61-80=7 \\
>80=3\end{array}$ & $\begin{array}{l}M=9 \\
F=6\end{array}$ & $\begin{array}{l}\text { Ill-literate }=5 \\
\text { Primary }=6 \\
\text { Middle }=2 \\
\text { High school }=1 \\
\text { High Secondary=1 } \\
\text { Graduate }=00 \\
\text { Post graduate }=00\end{array}$ & $\begin{array}{l}1=00 \\
2=2 \\
3=2 \\
4=6 \\
5=5\end{array}$ & $\begin{array}{l}\text { Hindu=9 } \\
\text { Muslim=5 } \\
\text { Other }=1\end{array}$ & $\begin{array}{l}\mathrm{GEN}=6 \\
\mathrm{OBC}=4 \\
\mathrm{ST}=3 \\
\mathrm{SC}=2\end{array}$ & $\begin{array}{l}\text { Married=1 } \\
\text { Un-married=6 } \\
\text { Separated }=4 \\
\text { Widowed }=4\end{array}$ \\
\hline OCD & $\begin{array}{l}0-20=5 \\
21-40=4 \\
41-60=3 \\
61-80=1 \\
>80=00\end{array}$ & $\begin{array}{l}M=5 \\
F=8\end{array}$ & $\begin{array}{l}\text { Ill-literate }=3 \\
\text { Primary }=3 \\
\text { Middle }=4 \\
\text { High school }=2 \\
\text { High Secondary }=1 \\
\text { Graduate }=00 \\
\text { Post graduate }=00\end{array}$ & $\begin{array}{l}1=1 \\
2=1 \\
3=4 \\
4=3 \\
5=4\end{array}$ & $\begin{array}{l}\text { Hindu=6 } \\
\text { Muslim=5 } \\
\text { Other }=2\end{array}$ & $\begin{array}{l}\mathrm{GEN}=5 \\
\mathrm{OBC}=4 \\
\mathrm{ST}=3 \\
\mathrm{SC}=1\end{array}$ & $\begin{array}{l}\text { Married=2 } \\
\text { Un-married=5 } \\
\text { Separated=5 } \\
\text { Widowed }=1\end{array}$ \\
\hline Phobia & $\begin{array}{l}0-20=00 \\
21-40=4 \\
41-60=3 \\
61-80=2 \\
>80=00\end{array}$ & $\begin{array}{l}\mathrm{M}=2 \\
\mathrm{~F}=7\end{array}$ & $\begin{array}{l}\text { Ill-literate }=1 \\
\text { Primary }=1 \\
\text { Middle }=3 \\
\text { High school=1 } \\
\text { High Secondary=1 } \\
\text { Graduate }=1 \\
\text { Post graduate=1 }\end{array}$ & $\begin{array}{l}1=00 \\
2=2 \\
3=2 \\
4=2 \\
5=3\end{array}$ & $\begin{array}{l}\text { Hindu }=4 \\
\text { Muslim }=5 \\
\text { Other }=00\end{array}$ & $\begin{array}{l}\mathrm{GEN}=4 \\
\mathrm{OBC}=2 \\
\mathrm{ST}=2 \\
\mathrm{SC}=1\end{array}$ & $\begin{array}{l}\text { Married=1 } \\
\text { Un-married=4 } \\
\text { Separated=3 } \\
\text { Widowed }=1\end{array}$ \\
\hline
\end{tabular}


In case of distribution of various psychiatric illnessdepression has highest prevalence in study population around $41.66 \%$ followed by mania $23.14 \%$, BPD and anxiety have equal prevalence around $20.37 \%$, phobia are least commonly found illness is $8.33 \%$ (Table 2.)

In case of distribution as per socio-demographic profile of psychiatric patients, it was found that psychiatric illness are more commonly present in patient who live separately it may be due to un-married state or separated after marriage, it may be widow or widower, this group constitute large proportion of study participants around $78.70 \%$. In these study most participant are Hindu by religion around $78.70 \%$, followed by Muslim is $19.44 \%$ and other are $1.85 \%$ (Table 3). It was also found that psychiatric illness was more common in ill-literate or in primary or middle class educated person and its prevalence was decreased as education level are increased and more common in lower socio-economic group people.

In case of socio-demographic relationship with various psychiatric illnesses-the disorders were divided into two groups-I). More prevalent psychiatric disorder (Table 4A) is those whose prevalence was greater than 20 in study population and II) low prevalent psychiatric disorder (Table 4B) is those whose prevalence was less than 20 in study population. In our study more prevalent psychiatric disorder were depression, mania, BPD, anxiety and low prevalent psychiatric disorder were schizophrenia, OCD and phobia. It was found that depression, anxiety, phobia are more common in middle aged female and who were ill-literate and have low socio-economic status and live separately. Whereas mania, BPD were found more common in young ill-literate or low educated male of low socio-economic group, but schizophrenia was more common in old age group participant.

\section{DISCUSSION}

In the present study most of the patients were belong to the age group of 21 to $60 \mathrm{yrs}$, the possible reasons for most of the subjects in this study being 21 to 60 years may be because this is the economically productive age group hence the chances of being exposed by the risk factors are highest at this age group. It may be due to that this age group is more self-concerned for health seeking behaviour. Therefore, these patients have been brought for the right care. Nevertheless, the presentation of psychotic disorders more in the relatively younger age group ( $<40$ years) has also been reported by Barua A, Pradhan SC and Chadda RK et al in the past. ${ }^{14-16}$

This distribution in this study is highly skewed toward males $(69 \%)$, which might be attributed to the prevailing gender bias in Indian society, where the illness of a male member is taken more seriously than that of a female patient. But in contrast it was found that females were more affected than males which are cited by Barua A, Shankar $\mathrm{H}$ et al study. The findings in the present study also support the fact that psychiatric hospital services are utilized more by male patients than by female patients. Other studies conducted by Wroster and Malla et al also found similar observations. ${ }^{18,19}$ This could be due to that these females are more likely to be illiterate, married, and from a lower income group. Similar findings and discussion was also quoted by Khanna and Lahariya et al. $^{20,21}$

The majority of patients in our study belonged to the lower socio-economic status, with low level of literacy. Generally the patients belonging to families from the, literate, and higher socio-economic status, preferred to take treatment from private practitioners or general hospital psychiatric setups. This may the reason that most of the participants of our study belonged to lower socio economic status.

In this study some of the psychiatric disorders found more prevalent like BPD, anxiety, depression and mania and some the illness like psyzophrenia, OCD and phobia found less prevalent among the patients. Similar distribution regarding prevalence of psychiatric morbidities were also reported by Bhatia et al. ${ }^{22}$ This less prevalent distribution of the some psychiatric illness in present study could be due to the perceived stigma associated with mental illnesses and with that of psychiatric hospitals that patients with mental illnesses do not seek the treatment from a specialty psychiatric hospital, as there is a common myth that psychiatric hospitals are meant for mentally ill persons, (patients having psychotic disorders) rather than for patients with any other psychiatric illness. This type of pattern of psychiatric disease somewhere takes attention of psychiatrists towards disease burden and treatment. Dasgupta R and Bagadia VN also quoted the same view regarding psychiatric disease burden and the treatment practices for the psychiatric illness. ${ }^{23,24}$ These are important lessons for the practitioners of psychiatric medicine in India.

\section{CONCLUSION}

In the present study it was found that the depression, anxiety, phobia are more common in middle aged female and who were ill-literate and have low socio-economic status and live separately. Whereas mania, BPD were found more common in young ill-literate or low educated male of low socio-economic groups so it can be recommended that improvement in education status, socio economic status and women empowerment along with counselling of single living person can improve mental health and eliminate stigma associate with mental health problem.

\section{ACKNOWLEDGEMENTS}

We would like to thanks to my seniors and colleague in my department of community medicine S.S.M.C Rewa India, for their support and we would also like to thanks 
to the members of psychiatric department who supported for smooth conduction of study and finally all the study participants of the study are also thankful.

Funding: No funding sources

Conflict of interest: None declared

Ethical approval: Not required

\section{REFERENCES}

1. WHO. Mental health: New understanding, New hope: World Health Report 2001. Geneva: World Health Organization. 2001:09-24.

2. Murray CJL, Lopez AD. Mortality by cause for eight regions of the world: Global Burden of Disease Study. Lancet. 1997;349:1269-76.

3. National Institute of Health and Family Welfare. National Mental Health Program. New Delhi: NIHFW; 2005. Accessible from: http://www.nihfw.orgndenihfw/html/ Programmes/ NationalMentalHealth.htm. Last accessed on 2007 Jul 12.

4. Reddy MV, Chandrasekar CR. Prevalence of mental and behavioral disorders in India: A meta-analysis. Indian J Psychiatry. 1998;40:149-57.

5. Ganguli HC. Epidemiological findings on prevalence of mental disorders in India. Indian J Psychiatry. 2000;42:14-20.

6. Government of India. Mental Health: An Indian Perspective, 1946-2003. New Delhi: Directorate General of Health Services. 2004:4-17.

7. Rogler LH, Cortes DE. Help-seeking pathways: A unifying concept in mental health care Am J Psychiatr. 1993;150:554-61.

8. Royal College of Psychiatrists, Royal College of Physicians, British Medical Association. Stigmatization within the medical profession. Council Report CR91. Royal College of Psychiatrists: London; 2001.

9. Demyttenaere K, Bruffaerts R, Posada-Villa J, Gasquet I, Kovess V, Lepine JP, et al. Prevalence, severity and unmet need for treatment of mental disorders in the World Health Organisation World Mental HealthSurveys. JAMA. 2004;291:2581-90.

10. Carpenter WT, Buchana RW. Schizophrenia Introduction and Overview. In: Kaplan Hl, Sadock BJ (editors).Comprehensive Text Book of Psychiatry. Philadelphia: Williams \& Wilkins. 1995;889-90.

11. Africa B, Schwartz RS. Schizophrenic Disorders. In: Howard H Goldman (editor). Review of General Psychiatry. New York Appleton \& Lange; 1995.
12. Kasyc M, Norquist GS. SchizophreniaEpidemiology, In: Kaplan Hl,Sadock BJ, editors. Comprehensive Text Book of Psychiatry. Philadelphia: Williams \& Wilkins. 1995:908.

13. Statistical Package for Social Sciences. SPSS version 10.0. USA: SPSS incorporate; 2007.

14. Barua A, Jacob GP, Mahmood SS, Udupa S, Naidu M, Roopa PS, et al. A study Onscreening for psychiatric disorders in adult population. Indian $\mathbf{J}$ Community Med. 2007;32:65-6.

15. Pradhan SC, Singh MM, Singh RA, Das J, Ram D, Patil B, et al. Firs caregives of mentally ill patients: A multicenter study. Indian J Med Sc 2001;55:203-8.

16. Chadda RK, Agarwal V, Singh MC, Raheja D. Help seeking behaviour of Psychiatric patients before seeking care at a mental hospital. Int $\mathrm{J}$ Soc. Psychiatry 2001;47:71-8.

17. Barua A, Shankar H, Jain A, Bhat VK, Kiran NU, Jayarama S. Hospital Based Study on Psychoses in Mangalore. 2006;31(1):30-1.

18. Worster A, Haines T. Advanced statistics: Understanding Medical Record review (MRR) studies. Acad Emerg Med. 2004;11:187-92.

19. Malla AK, Norman RM. Mental hospital and general hospital psychiatric units: A comparison of services within the same geographic area. Psyche and Med. 1983;13:431-9.

20. Khanna RK. Sex difference in mental health service utilization. Soveneire, ANCIPS, NewYork. 1995:928.

21. Lahariya C, Singhal S, Gupta S, Mishra A. Department of Community Medicine, G.R. Medical College, and the associated J. A. Group of Hospitals, Gwalior Mansik Arogyashala, Gwalior, India.

22. Bhatia MS. Psychiatric morbidity in GHPU adjoining mental hospital. J Mental Health Human behaviour. 2001;6:114-8.

23. Dasgupta R, Dasgupta C. Catie and Cutlass (UK): Is it time psychiatrists' start changing their practice? The debate goes on!. Indian J Psychiatry. 2009;51:161-2.

24. Bagadia VN, Shah LP, Pradhan PV, Gada MT. Treatment of mental disorders in India. Progress in Neuropsychopharmacology. 1979;3:109-18.

Cite this article as: Adhikari P, Niranjan A, Ahuja SK, Gour N, Sanjeev K, Manish K. Assessment of socio-demographic determinants of psychiatric patients attending psychiatry outpatient department of a tertiary care hospital of Central India. Int J Community Med Public Health 2016;3:764-9. 